\title{
Comparative Analysis of Tourism Potential Assessment Methods
}

\author{
Olga V. Karpycheva 1[ORCID 0000-0002-2050-9635], \\ Anastasiya N. Rusina $\left.{ }^{1 *[O R C I D} 0000-0002-1477-2840\right]$, \\ Ekaterina A. Yakimova 1[ORCID 0000-0001-8895-2708]
}

\author{
${ }^{1}$ Siberian Federal University, Krasnoyarsk, Russia \\ kozitsina55@mail.ru
}

\begin{abstract}
The tourism industry is currently experiencing serious difficulties related to the COVID-19 pandemic. There has been a significant decline in outbound tourism flows due to the closure of national borders and the introduction of restrictions by countries that were traditionally considered the most attractive for tourists. At the same time, the reduction of outbound tourism can be seen as an opportunity for the development of domestic tourism, including intra-regional tourism. Krasnoyarsk Krai is the second largest subject of the Russian Federation, which has significant opportunities for tourism development, however, we notice a low level of inbound and domestic tourism development due to insufficient development of tourism infrastructure, as well as low level of people's awareness of potential places of attraction in the region. To develop tourism in Krasnoyarsk Krai it is necessary to carry out large-scale studies to identify the most promising tourist flows, to strengthen marketing activity on the part of private business and tourism management bodies, to form a tourist brand of the region, to develop a mechanism for managerial decision-making in the field of tourism development and support. In our opinion, the initial stage of research and decision-making complex should be the assessment of the region's tourism potential. The article is devoted to the research and comparative analysis of approaches to the assessment of tourist potential of territories. Assessment of tourist potential is the initial stage of a systematic approach to making management decisions for the development of the tourism industry at any level, including intra-regional. Comparative analysis of approaches to tourism potential assessment allowed us to identify the methodology that is most suitable for the specifics of Krasnoyarsk Krai, as well as further areas for its improvement.
\end{abstract}

Keywords: territory attractiveness, tourism potential, natural potential, historical and cultural potential, infrastructure potential, potential of specially protected natural areas

\section{INTRODUCTION}

Tourism is one of the most important sectors of the global economy. Thus, tourism accounts for about $7 \%$ of world trade, with one in ten jobs directly or indirectly generated by tourism. At the same time, the tourism industry is one of the sectors most affected by the COVID-19 pandemic. According to the experts of the World Tourism Organization, the fall in revenues from tourism activities is $60-80 \%$, more than $100 \mathrm{mln}$ people may lose their jobs [1]. At the same time, the crisis caused by the closure of national borders in many countries has led to increased interest in domestic tourism, which is, to some extent, has a forced nature for consumers. Nevertheless, the interest in domestic tourism can be seen as an opportunity for the development of Russia's tourism industry. Thus, according to the results of the survey of organizations engaged in tourism activities to assess the demand for domestic tourism services in the II quarter of 2021, $29 \%$ of their total number noted an increase in demand for domestic tourism services, while a decrease in demand was noted by $20 \%$ of respondents [2].

We can talk about the existence of a long-term federal and regional policy to support tourism in the Russian Federation. However, current global trends in tourism require innovative, proactive and 
comprehensive actions to ensure the competitiveness of Russian tourism. This is due, first of all, to the peculiarities of budget financing of measures to support the industry [3].

In addition to the traditional places of attraction, such as Moscow, St. Petersburg or Sochi, there is a growing interest in intra-regional tourism. The development of domestic tourism is one of the priority objectives of the "Strategy for Tourism Development in the Russian Federation until 2035" (hereinafter - Strategy) [4].

One of the Strategy's targets is to double domestic tourism trips by 2035 . The obstacles to the development of domestic tourism in Russia include low level of awareness of potential consumers about the opportunities of domestic and intra-regional tourism, insufficient development of tourism infrastructure, low level of marketing activity, lack of decision-making mechanism of investment nature that allows identifying places of attraction with the highest value of tourist potential.

Assessment of tourist potential of territories, in our opinion, is the initial stage of a comprehensive approach for the development of measures aimed at the development of domestic tourism destinations and formation of a competitive tourist product.

The analysis of the literature allows us to distinguish two directions in the methods of tourist potential assessment: descriptive (qualitative) and quantitative. In general terms the tourism potential is considered as the ability of the territory to attract and receive tourists given the availability of relevant resources, their effective use, etc. Tourist potential is defined as a set of natural, cultural, historical and socio-economic prerequisites for the organization of tourist activity in a particular area [5].

The understanding of tourist potential is not limited to resource factors: operational factors are essential. They include various elements of infrastructure that determine the ability of the territory to receive tourists. Related to the notion of tourism potential is the notion of tourist attractiveness, which can be evaluated from the perspective of supply and demand. Attractiveness from the supply side is assessed based on the quantity and quality of attractions in a particular area [6].

The attractiveness of an area from the point of view of demand depends on its perception by potential tourists and the interest this area generates. Currently, there are a significant number of approaches to the assessment of tourism potential.

\section{MATERIALS AND METHODS}

The aim of the study is to compare and choose the methodologies best suited for assessing the tourist potential of Krasnoyarsk Krai territories.

Krasnoyarsk Krai is the second largest subject of the Russian Federation and it possesses significant natural and climatic, socio-economic, cultural and historical tourist resources. Thus, about $6 \%$ of the region's territory is occupied by specially protected natural areas of federal, regional and local significance. The region is home to 2120 cultural heritage sites, of which 1067 are archaeological heritage sites. The availability of resources is a prerequisite for the development of domestic and inbound tourism, which is currently assessed as insufficient due to low transport accessibility of some territories, uneven level of development of tourism infrastructure, lack or little information about places of attraction. The share of tourism industry in GRP of Krasnoyarsk Krai is only $0.3 \%$.

The concept of tourism industry development in the Krasnoyarsk Krai provides for a cluster approach based on the interaction between the authorities and private businesses and compliance with the principles of attractiveness, accessibility, comfort, safety, payback, profitability, socio-economic and budgetary efficiency. The initial stage of cluster formation is an inventory of tourist products and assessment of tourist potential of Krasnoyarsk Krai territories.

The materials for the study are the works of Russian and foreign authors. Research methods used: theoretical analysis of literary sources, structural analysis, synthesis, classification, methods of expert evaluations.

\section{RESULTS}

The methods of tourist potential assessment can be divided into qualitative and quantitative. In addition, there are a number of methods that allow to combine the two approaches. A number of approaches are also used in tourism potential analysis, allowing to typify the methods in a particular way. The paper by R.I. Sukhova and Y.S. Yatsenko [7] distinguishes the types of tourist potential assessment presented in Table 1 .

The economic approach is essential in the assessment of tourism potential, as it aims to develop a management decision support system from the perspective of allocation of financial support measures to stimulate tourism of individual 
territories. Financial resources for support are limited, and it necessitates the development of such a system.

Table 1. Types of assessments of the tourism potential of territories

\begin{tabular}{|l|l|}
\hline $\begin{array}{c}\text { Approach to } \\
\text { Tourism Potential } \\
\text { Assessment }\end{array}$ & \multicolumn{1}{|c|}{$\begin{array}{c}\text { Purpose and Practical Scope of } \\
\text { the Approach }\end{array}$} \\
\hline $\begin{array}{l}\text { Functional and } \\
\text { technological }\end{array}$ & $\begin{array}{l}\text { Tourist zoning, determination of } \\
\text { tourist specialization of the territory }\end{array}$ \\
\hline Biomedical & $\begin{array}{l}\text { Determining the seasonality of } \\
\text { demand for the territory's tourism } \\
\text { products }\end{array}$ \\
\hline Psycho-aesthetic & $\begin{array}{l}\text { Marketing aspects of territory } \\
\text { promotion, image formation }\end{array}$ \\
\hline Economic & $\begin{array}{l}\text { Assessment of tourism activities } \\
\text { from the perspective of their impact } \\
\text { on the socio-economic situation of } \\
\text { the territory }\end{array}$ \\
\hline
\end{tabular}

Source: [7]

When assessing the tourist potential, it is possible to use well-known methods of strategic management, in particular the SWOT-analysis [8]. It is possible to use this method to assess the tourist potential of territories of different levels: country, regional and intra-regional. The use of quantitative SWOT-analysis procedures allows taking into account the different degree of importance of external and internal environment factors for territories with different potential.

Application of qualitative (descriptive) approaches to the analysis of tourist potential of territories, as a rule, consists in compiling a "tourist passport" of the territory with a detailed description of objects of natural, cultural and historical character and subsequent elaboration of proposals for development and marketing activity. However, the use of descriptive approaches greatly limits the directions of decision-making in the field of enhancing tourist attractiveness of the territory, as it has limited opportunities in terms of comparing different territories from the perspective of tourism potential.

Quantitative methods of tourism potential assessment are based, first of all, on the hierarchy of potential components. Thus, for some territories the most relevant factors will be of environmental and climatic nature, for others - cultural, historical or infrastructural. A widely known approach in the quantitative assessment of tourism potential is the method of summing up weighted estimates of potential factors expressed in point estimates. The effectiveness of the methodology is noted for the purposes of determining the most promising territories from the standpoint of tourism development, as well as a mechanism for the distribution of financial support funds.

L. Yan, B.W. Gao, M. Zhang [9] propose a model of estimating tourist potential based on two complex components: resource and characteristics of the state of development. Resources include: aesthetic and historical value, level of awareness, environment, complementarity with the attractions of neighboring areas, authenticity, and value for money. Among the indicators that determine the state of development of the territory, the authors include transport accessibility and proximity to attractions, the availability and comfort of accommodation and catering, the availability of information resources, as well as the duration of stay. To assess each of the indicators, the authors propose using an ordinal scale of 1 to 7 points, with weighting values of 0.2 (lowest value), 0.4, 0.6, 0.8, and 1.0 (highest value). The importance of this or that indicator is determined by applying the method of expert evaluations, as well as the results of a survey of respondents. This model has been tested by the authors to assess the tourism potential of the territories of China with cultural and historical heritage.

L.I. Kulakova and V.A. Osipov proposed their own methodology for assessing the tourist potential [10]. Among the leading factors determining the level of tourist potential, the authors distinguish historical, cultural and infrastructural potential, the potential of natural conditions and specially protected natural areas (determination of these components, in our opinion, is relevant to the Krasnoyarsk Krai as a region with a significant number of protected areas). Comprehensive assessment of the tourist potential of the territory is calculated by the formula (1):

$$
P=v_{1} * K_{0}+v_{2} * T_{0}+v_{3} * N_{0}+v_{4} * B_{0},(1)
$$

where $\mathrm{P}$ - tourist and recreational potential; $\mathrm{K}_{0}-$ relative historical and cultural potential; $\mathrm{T}_{0}-$ relative potential of specially protected natural areas; $\mathrm{N}_{0}-$ relative potential of natural conditions; $\mathrm{B}_{0}-$ relative infrastructure capacity; v1-v4 - weighting coefficients.

The elements and components of the methodology are presented in Figure 1. 


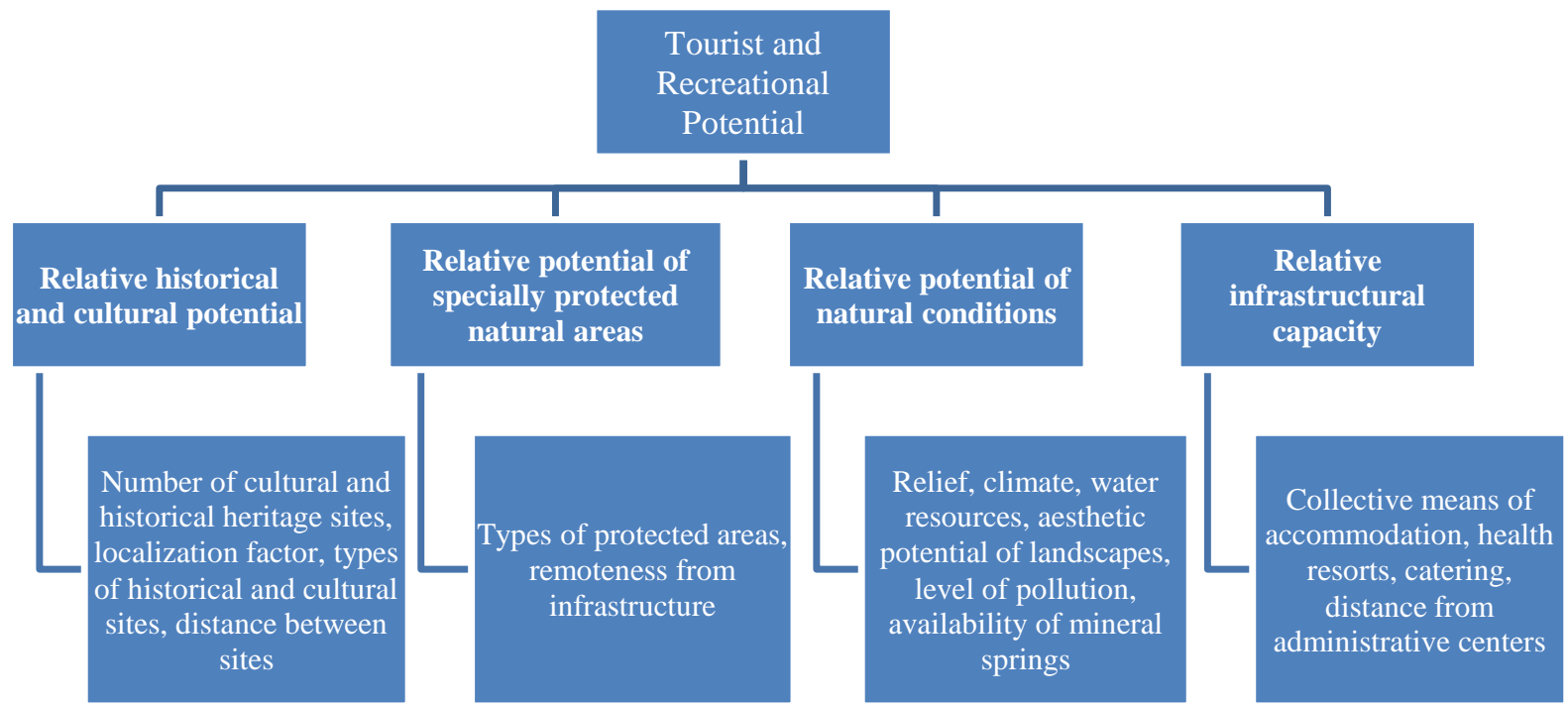

Figure 1. Components of the tourist potential assessment model

Source: [10]

Historical and cultural potential is determined by the number of cultural and historical sites of the territory, the number of such sites in the region, as well as the localization factor, to determine the value of which the authors recommend an inventory of historical and cultural sites with subsequent correlation of the density of their distribution. The advantage of this methodology is the scale proposed by the authors for grading the distance between tourist sites to translate the distance into scores. In our opinion, this will allow to take into account the geographical features of Krasnoyarsk Krai and its administrative-territorial division.

Among the indicators that determine the potential of specially protected natural territories are the different types of these territories (national park, reserve, reserve of local importance, etc.). Weighting coefficients that take into account the status of a specially protected natural area are also used.

Since Krasnoyarsk Krai has significant natural resources, the assessment of the relative natural capacity is a necessary element of a comprehensive assessment. However, a significant aspect that may have a negative impact on the assessment of this type of potential is the current negative image of the region as a region with significant environmental problems, as the authors propose a scale of assessment of natural conditions, providing not only positive but also negative values.

Krasnoyarsk Krai is often seen as an industrial region oriented towards raw material production. The problems associated with the development of tourism of such regions are discussed in connection with the need to diversify the economy and find new sources of budget revenues [11].

Relative infrastructure capacity is calculated based on the calculation of collective places of accommodation: hotels, recreation centers, health resorts. It is also proposed to take into account the distance to the nearest administrative center considering the characteristics of the transport infrastructure.

Modern tourism cannot exist without modern information technology. The increasing widespread use of the Internet, the use of mobile devices facilitate the task of raising awareness of tourist products and destinations. Krasnoyarsk Krai with its vast territories and magnificent landscapes is very attractive for many types of tourism: mountain, water, environmental, historical, business, etc. [12].

This region is capable of creating a competitive tourism industry. The territory of the region is located in three climatic zones: temperate, arctic and subarctic. Comparative analysis of tourism development conditions in Krasnoyarsk Krai and other regions of the Russian Federation revealed problems of tourism industry development: low and very low transport accessibility in some areas of the region, as well as poor awareness of potential tourists and lack of marketing activity. Among the types of tourism directions in the region, the most preferred are active, cultural and educational, as well as amateur tourism. Currently, more than $90 \%$ of internal tourist flows are formed by domestic tourists, while the contribution to the development 
of the region's economy remains insignificant. In our opinion, the development of measures to promote tourism in the Krasnoyarsk region must begin with a comparative assessment of the tourist potential of the territories, which are characterized by a very uneven level of development in terms of tourism.

A comparative analysis of approaches to assessing the tourist potential of territories has revealed several basic approaches to its assessment. Using only one approach (qualitative or quantitative) is insufficient to form a decision support system to stimulate tourism development.

In our opinion, to achieve the greatest effect in the development of domestic and inbound tourism in the Krasnoyarsk region, it is important to use a comprehensive approach to the assessment of its tourist potential. Thus, the use of descriptive methods will contribute to "passportization" and the formation of a holistic picture of the availability of resource and infrastructure components, and the use of quantitative methods of assessment will determine the specificity of tourism orientation of individual territories of Krasnoyarsk Krai and highlight the most promising areas of development.

The considered quantitative methods of assessing the tourist potential of territories are based on several common points, namely the use of weighting coefficients that determine the hierarchy of factors determining the potential, as well as point estimates of the degree of manifestation of these factors. In our opinion, the most acceptable methodology for assessing the tourist potential of the Krasnoyarsk Krai is the one proposed by L.I. Kulakova and V.A. Osipov, because it takes into account geographical, climatic and natural conditions of the region.

\section{DISCUSSION}

At the same time, the use of the methodology of tourist potential assessment based on statistical and other quantitative indicators, from our point of view, represents an approach only from the supply side, without taking into account the specifics of demand for tourist products of the territory and its perceived tourist attractiveness. In our opinion, the development of this methodology can be carried out by introducing a system of monitoring of the tourism industry in the region, the parameters of which will be tracking changes in infrastructure development, as well as changes in the direction of tourist flows and the perception of places of attraction by potential consumers.

\section{CONCLUSION}

Comparative analysis of methods of tourist potential assessment allowed to determine the most appropriate methodology for assessing the tourist potential of the Krasnoyarsk Krai. To improve this methodology it is proposed to introduce a system of monitoring the state of the tourism industry, as well as changes in consumer preferences.

\section{AUTHORS' CONTRIBUTIONS}

Anastasiya N. Rusina - analysis of the relevance of the problem under study, analysis of statistics. Ekaterina A. Yakimova - analysis of methods of assessment of tourist potential. Olga V. Karpycheva - analysis of methods of tourist potential assessment, final approval of the version for publication.

\section{ACKNOWLEDGMENTS}

The study was carried out with the support of the regional state autonomous institution "Krasnoyarsk Regional Fund for Support of Scientific and Scientific-technical Activity" within the framework of the implementation of the project: "Development of information-analytical system for monitoring the state and potential assessment of the tourism industry of Krasnoyarsk Krai for the strategic management decision-making", application code No. 2021021007411.

\section{REFERENCES}

[1] "Stepping up support and coordination for a safe and sustainable recovery of tourism", 2020, World Tourism Organization. A United Nations Specialized Agency. (In Russ.). Retrieved from https://www.unwto.org/ru/news/stepping-upsupport-and-coordination-for-a-safe-andsustainable-recovery-of-tourism

[2] Federal State Statistics Service, 2021. (In Russ.). Retrieved from https://rosstat.gov.ru/folder/23457

[3] K.A. Miloradov, T.S. Romanishina, A.A. Kovalenko, N.G. Bondarenko, J.V. Andrianova, "An Efficient Strategy for the Development of Tourism at Regional Level", European Research Studies Journal, 2018, vol. 21(4), pp. 208-221.

[4] "Strategy of tourism development in the Russian Federation for the period until 2035" 
[Strategiya razvitiya turizma $\mathrm{v}$ Rossijskoj Federacii na period do 2035 goda] (approved by the Government of the Russian Federation Order No. 2129-r dated September 20, 2019), 2019. (In Russ.). Retrieved from https://goo.su/8e28

[5] R. Shohan, A. Toleuuly, Z.K. Assadova, "Tourist potential and prospects of tourism industry of Kazakhstan”, Education and Science Without Borders, 2012, vol. 3(5), pp. 34-37.

[6] S. Formica, "Destination attractiveness as a function of supply and demand interaction", Unpublished doctoral thesis, Blacksburg: Virginia Polytechnic Institute and State University, 2000.

[7] R.I. Sukhov, Yu.S. Yatsenko, "Conducting the systematization and evaluation of existing methodical developments for the assessment of tourist potential of territories aimed at identifying the possibilities for implementation of cluster initiatives", Fundamental Research, 2018, vol. 11(2), pp. 284-289. (In Russ.).

[8] P.E. Murphy, A.E. Murphy, "Strategic management for tourism communities: Bridging the gaps", Clevedon: Channel View Publications, 2004.

[9] L. Yan, B.W. Gao, M. Zhang, "A mathematical model for tourism potential assessment", Tourism Management, 2017, vol. 63, pp. 355365. DOI: 10.1016/j.tourman.2017.07.003

[10]L.I. Kulakova, V.A. Osipov, "Methodical approaches to assessment of the tourism and recreational potential of Russian regions", Russian Journal of Entrepreneurship, 2017, vol. 18(24), pp. 4261-4272. (In Russ.). DOI: 10.18334/rp.18.24.38687

[11]L.G. Kiriyanova, "Mining and tourism: Is it possible to sustain resource-driven region?", Bulletin of the Tomsk Polytechnic University. Geo Assets Engineering, 2020, vol. 331(11), pp. 208-216.

DOI: $10.18799 / 24131830 / 2020 / 11 / 2903$

[12] A. Nozhenkov, A. Korobko, "Technologies and applications for the support of tourism in Krasnoyarsk region”, IOP Conference Series: Materials Science and Engineering, 2020, vol. 862, p. 052066. DOI: 10.1088/1757899X/862/5/052066 